\title{
Food Security, Environmental Health, and the Economy in Mexico: Lessons Learned with the COVID-19
}

\author{
Rebeca Monroy-Torres ${ }^{1} * * \mathbb{B}$, Ángela Castillo-Chávez ${ }^{2}$, Erika Carcaño-Valencia ${ }^{3}$, Marco Hernández-Luna ${ }^{1}$, \\ Alex Caldera-Ortega ${ }^{3}{ }^{1}$, Alma Serafín-Muñoz ${ }^{4}{ }^{\circledR}$, Benigno Linares-Segovia ${ }^{1}$, Karen Medina-Jiménez ${ }^{2}$, \\ Octavio Jiménez-Garza ${ }^{1}{ }^{(0)}$, Monserrat Méndez-Pérez ${ }^{2}$ and Sergio López-Briones ${ }^{1}$ (i)
}

1 Cuerpo Académico de Medicina Traslacional, Departamento de Medicina y Nutrición, División de Ciencias de la Salud, Universidad de Guanajuato, Campus León, León, Guanajuato 37670, Mexico; ahl_marco@yahoo.com.mx (M.H.-L.); blinares70@gmail.com (B.L.-S.); ojimenezgarza@yahoo.com (O.J.-G.); lobris@yahoo.com (S.L.-B.)

2 Observatorio Universitario de Seguridad Alimentaria y Nutricional del Estado de Guanajuato, León, Guanajuato 37299, Mexico; angelacastillo14@gmail.com (A.C.-C.); akameji4kar@gmail.com (K.M.-J.); monsse.meendez@gmail.com (M.M.-P.)

3 División de Ciencias Sociales y Humanidades, Universidad de Guanajuato, Campus León, León, Guanajuato 37670, Mexico; erikacarcano@gmail.com (E.C.-V.); arcaldera@gmail.com (A.C.-O.)

4 Departamento de Ingeniería Ambiental, División de Ingenierías, Universidad de Guanajuato, Campus, Guanajuato 36000, Mexico; sermuah@ugto.mx

Citation: Monroy-Torres, R.; Castillo-Chávez, Á.;

Carcaño-Valencia, E.

Hernández-Luna, M.; Caldera-Ortega,

A.; Serafín-Muñoz, A.;

Linares-Segovia, B.; Medina-Jiménez,

K.; Jiménez-Garza, O.; Méndez-Pérez,

M.; et al. Food Security,

Environmental Health, and the

Economy in Mexico: Lessons Learned with the COVID-19. Sustainability 2021, 13, 7470. https://doi.org/ $10.3390 /$ su13137470

Academic Editor:

Mohammad Valipour

Received: 13 April 2021

Accepted: 8 June 2021

Published: 5 July 2021

Publisher's Note: MDPI stays neutral with regard to jurisdictional claims in published maps and institutional affiliations.

\begin{abstract}
The COVID-19 pandemic showed an impact mainly on the health of people and the economy of households. The levels of food security in the world's households, especially in Mexico, have decreased. When people do not have food security, their health is compromised and they have financial problems; on the other hand, environmental deterioration has a link with food security. The purpose of this review is to analysis of the current situation in Mexico of food security, environmental health and economy, the main lessons learned in these areas and their proposals integrating public policies. A review was carried out in the main databases (MEDLINE, Embase, CINAHL Plus, Web of Science, CAB Abstracts y PAIS Index) with the following keywords and according to the MeSH terms: Food security, food insecurity, environmental health, public policies, environmental, production, integrating the word COVID-19 in English and Spanish. Only 44.5\% of Mexican households presented food security. For food insecurity, $22.6 \%$ had moderate and severe food insecurity, while $32.9 \%$ had mild insecurity. Food insecurity and the health impacts of environmental origin (waste management during the coronavirus pandemic, water contaminated by bacteria, viruses, and toxins; air pollution) generates impacts on economic activity by not offering food that meets health regulations. Without the application of cost-effective measures and interventions for the prevention and control of patients with obesity, the direct costs for 2023 will amount to 9 million dollars, which worsens the household economy. Despite having laws and policies on the right to food, a healthy environment (water), and opportunities for economic growth, these human rights are not fulfilled. The conclusion is that it is necessary to use a health and agroecological model to promote public policies (health, environment, and economy) that aims to prevent the discussed issues, with multidisciplinary and intersectoral interventions (government, academia, researchers, civil society organizations, industry, and population). This upholds the human right that all people should enjoy an adequate, healthy environment and have access to high-quality food.
\end{abstract}

Keywords: food security; environmental health; economical system; COVID-19

\section{Introduction}

In December 2019, SARS-COV-2, still of uncertain origin, causing the COVID-19 disease, was detected for the first time in Wuhan, China [1]. On 11 March 2020, the World Health Organization (WHO) declared a pandemic, and by December, more than 
one million deaths worldwide have been caused by COVID-19, mainly with economic and health impacts. Mexico, one of the largest countries in terms of territory and population in the Latin American continent, presented 209,000 confirmed deaths and 2,028,000 infections by 10 April 2021 [2].

According to the 2018 National Health and Nutrition Survey (ENSANUT) (Table 1), compared to the 2012 survey, there was an increase in the figures for diabetes (10.3\%), hypertension (18.4\%), dyslipidemias (19.5\%), obesity and overweight (35.6\%). In 2012, 70\% of households had food insecurity; this figure was $55.5 \%$ in 2018. Unfortunately, an increase in the consumption of sugary drinks has also been observed [3]. This can be explained by the loss of Mexican cultural identity, changes in lifestyles and the lack of public policies on health prevention [4].

Table 1. Comparison of the percentages of some of the main results of the National Health and Nutrition Surveys (ENSANUT) of 2012 vs. 2018 [3].

\begin{tabular}{ccc}
\hline Indicator & Survey-2012 & Survey-2018 \\
\hline Food security & $30 \%$ & $48.9 \%$ \\
Diarrheal disease in infants of 0 to 4 years & $11 \%$ & $11.8 \%$ \\
Diabetes in population of 20 years and more & $9.2 \%$ & $10.3 \%$ \\
Hypertension in population of 20 years and more * & $16.6 \%$ & $18.4 \%$ \\
Cholesterol and triglycerides in the population of 20 years & $13 \%$ & $19.5 \%$ \\
and more * & $9.2 \%$ & $5.1 \%$ \\
Tobacco consumption in the population of 10 to 19 years & $14.4 \%$ & $28.6 \%$ \\
\hline Exclusive breastfeeding & &
\end{tabular}

*Women have the highest percentages [3].

Poor nutrition affects0020productivity and general well-being of people. Malnutrition or patients with obesity or overweight frequently had vitamins and minerals deficiencies are the cause of neurocognitive deterioration, emaciation, anemia, decrease and immunosuppression, increasing vulnerability to infectious diseases. For overweight and obesity increase, the risk of chronic non-communicable diseases, such as diabetes, heart disease, osteoarthritis, cancer, and the immune system is also affected by the inflammatory processes that obesity generates $[5,6]$.

Objective: a literature review of the dimensions of Food Safety and the variables directly related to the presence of food safety such as Environmental Health and the Economy was carried out, with the aim of guiding proposals derived from the lessons learned with the contingency by COVID-19.

\section{Materials and Methods}

Design: Literature review

Data sources: MEDLINE, Embase, CINAHL Plus, Web of Science, CAB Abstracts, and PAIS Index with the following keywords and according to the MeSH terms: Food security, food insecurity, environmental health, public policies, environmental, production, integrating the word COVID-19 in English and Spanish (Figure 1). 


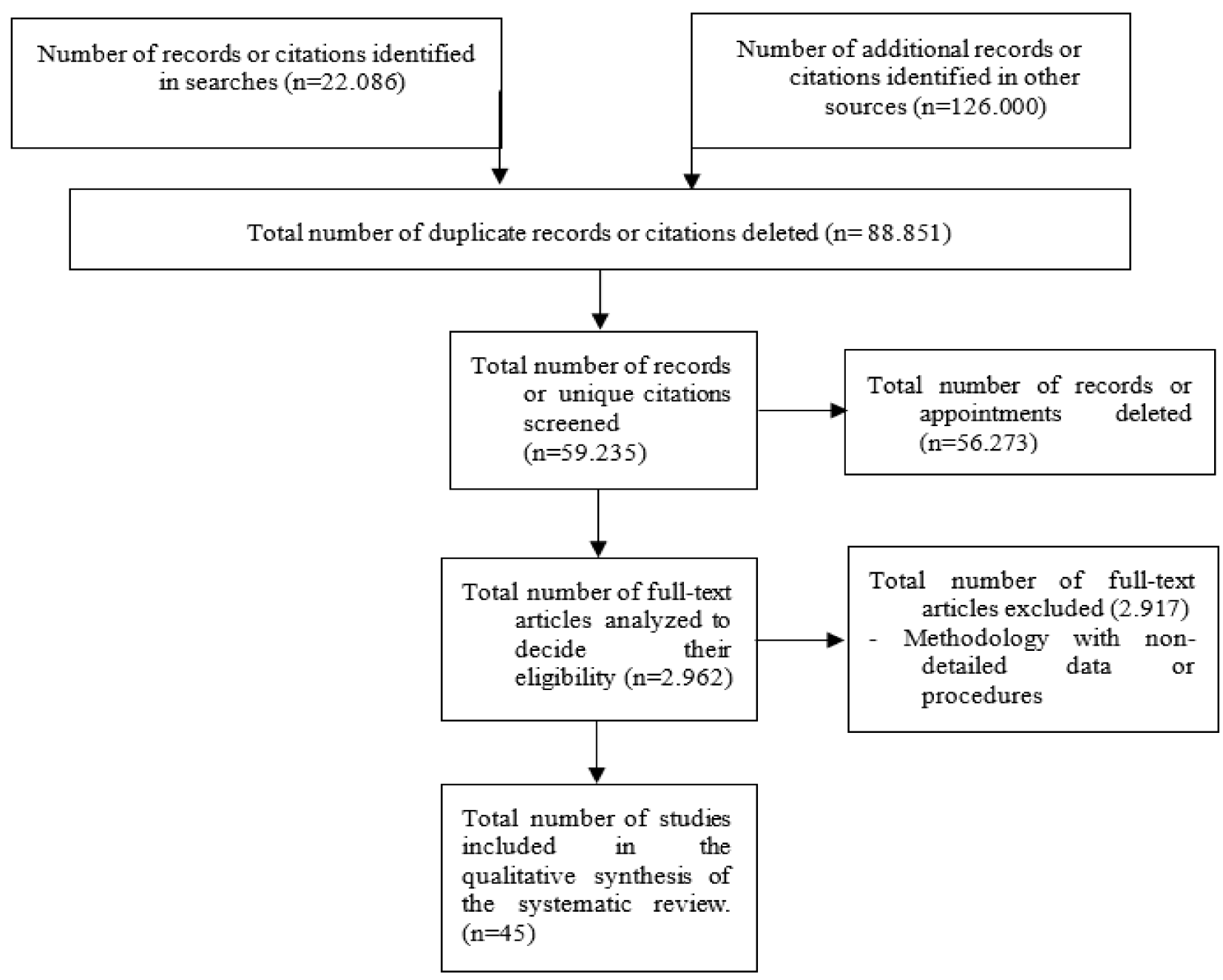

Figure 1. Article selection criteria and review structure with main concepts of food security, environmental health and economy.

\section{Selection criteria:}

- Articles that will integrate the food and nutritional security situation in consideration of local and national public policies.

- Articles that will present an analysis of databases in relation to elements of food security (access and availability of food) and indirect variables that contribute to the presence of food security such as: investment and agricultural development plans, investment policies to preserve water, and diseases associated with environmental pollution. This in the presence and absence of COVID-19.

Data analysis: Articles that specify the instruments for both population assessment and database analysis. In addition, they will present results in terms of prevalence, comparison analysis regarding changes in food security figures and indirect variables that impact food security (environmental health and economy).

\section{Literature Review}

\subsection{Food Security}

Food security is defined when everyone, constantly and permanently have access to a healthy and culturally acceptable diet, which provides essential nutrients for proper development and growth of people [7]. More than 820 million of people suffer hunger in the world and approximately 2 billion of people suffer some type of food insecurity. Food insecurity in Latin America and the Caribbean increased by $4.7 \%$ to $6.4 \%$ in only three years (2014 to 2016) [8]. Lack of access to healthy foods, increases the risk of presenting 
poor nutrition (due to deficiency or excess) [9]. In addition to this, households headed by women present a greater risk of having some degree of food insecurity associated with the presence of obesity and overweight (Relative risk $R R=1.28$ to $2.97 ; 95 \%$ Confidence interval CI: 1.08-1.44 to 1.52-6.14), to lower economic income of women, years of education, number of children, living in a rural area [10] and cultural practices [4].

In Mexico, since 2012, the levels of food insecurity have increased (2012 to 2014 it was $21.6 \%$ to $23.4 \%$, respectively). In $2018,44.5 \%$ of households presented food security. Regarding the levels of food insecurity, $22.6 \%$ had moderate and severe food insecurity while $32.9 \%$ had mild insecurity [3,10]. Stability, availability, accessibility, consumption, and biological incorporation are part of the dimensions of food security. Availability, physical and economic are the result of domestic food production, imports and exports in a country, food supports and the capacity for storage and transportation. To have access to healthy foods, economic income or to have salary, allows reaching the other dimensions of food security, but this access depends on the supply and demand of consumers and the food policies of the countries [11]. The distance between the centers of production, distribution, and the infrastructure available to carry out the internal agri-food trade influences the availability for food to be purchased at home [12]. In 2012, 70.1\% of the food consumed in Mexican households came from grocery stores (24.9\%), specific brand stores (22.3\%), supermarkets $(13.7 \%)$ and open markets $(9.2 \%)$. However, this behavior is different for each region of the country [4], which have generated a greater concentration and accessibility of processed instead fresh products only in certain regions of the country. An important point of availability is the destination dynamics of agricultural production, where $49 \%$ of the country's agricultural production units, 51.5\% sell their harvest to intermediaries, $25.5 \%$ sell direct to the consumer, $11 \%$ to the industry and the rest corresponds to food markets, supermarkets, or warehouses [9]. In the case of fresh food, its highest concentration is in supply centers, where $95 \%$ of the food in the basic basket can be accessed. This concentration of markets, which is migrating to become increasingly urban, generates a situation of vulnerability and informality (they do not have employment benefits and the establishments are not legally registered) for producers who cannot sell their products in these spaces due to the difficulty of marketing, transportation or storage, lack of fair prices, competitive and a lack of organization among local producers. This explains the increased offer of intermediaries as a part of the food production and distribution chain at the current economic system [13].

An adequate nutritional state is achieved with a balance between consumption (nutrient and energy intake) and energy expenditure. Genetic, biological, cultural, psychological, and environmental factors influence and determine sufficient, excessive or insufficient energy intake according to the requirement and type and variety of foods that are acquired by people and the distribution in the members of a household or family [14-16]. Hygiene in food preparation (safety) is important prevention action for avoiding health risk [17,18]. Foodborne illnesses continue being a public health problem and contribute to the prevalence of diarrheal diseases with impacts on morbidity and mortality on 2.2 million people per year and mostly children under 5 years of age [19]. Food safety is part of the production and distribution systems - that is, economic dynamics [20]. Data from the WHO estimate that each year more than 400,000 people die from infectious foodborne diseases [21,22]. More than 9 million cases of infections associated with the consumption of contaminated food are reported each year in the United States [23]; the meat was the main food followed by dairy products, cereals, and vegetables [24]. In addition to the effects on people's health, the lack of hygiene in food has an impact on the economy of households and companies. In food companies it will affect their image and reputation [25].

Lack of access to drinking water is often present in households that suffer from poverty; to access to basic housing, water and sewerage services influences and impacts food hygiene. In addition to being an indicator of health, access to water is a human right, which is why it is part of the Six " $\mathrm{P}$ " model. In the Six " $\mathrm{P}$ " model, the dimensions that cause poor nutrition are integrated (Figure 2) [26]. 


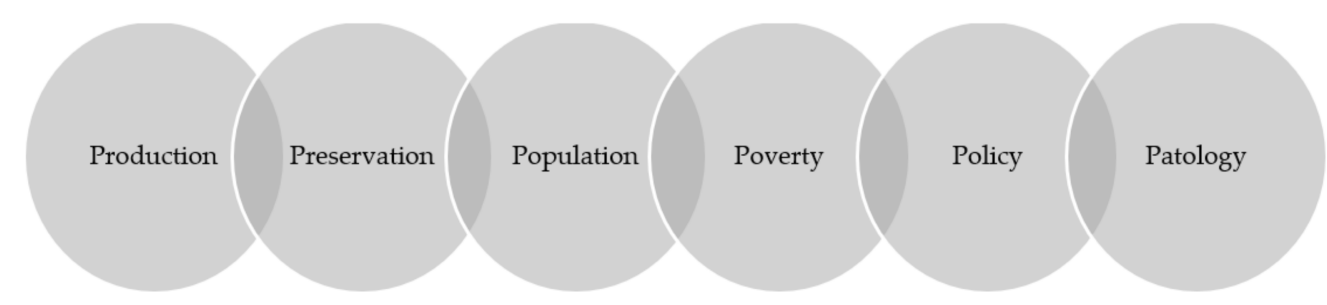

Figure 2. The Six "P's", causes of poor nutrition conditions.

\subsection{Emerging Diseases}

Emerging diseases such as the SARS-CoV-2 virus [27] have been associated with the deterioration of health due to social changes, economic and environmental impacts, leading to greater susceptibility (morbidity and mortality) to this infectious agent [28]. Among the emerging diseases that have emerged in recent years are the influenza virus (H1N1 and H5N1 strains), coronavirus (SARS, MERS-COV, SARS-CoV-2), Zika virus and Chikungunya $[29,30]$ and reemerging viruses such as Ebola [31,32].

The SARS-CoV-2 pandemic has demonstrated us how this emerging disease collapsed health systems worldwide. However, it is important to mention that the SARS-CoV-2 virus joins the list of infectious agents that have found a new host in humans. More than 1400 infectious organisms have been described, including bacteria, viruses, parasites, fungi, and prions [33]. In irrigation systems used in Northwest Mexico, the presence of Enteropathogenic and Enterotoxigenic E. Coli was detected [34,35]. Another problem in addition to the health one is the toxicological one such as the presence of antibiotics that has generated their resistance. Broad spectrum antibiotic administration practices in farm animals as a prophylactic measure $[35,36]$. There is evidence that a large majority of bacteria isolated from food are resistant to a wide range of antibiotics and pose a risk to human health [34,37].

On the other hand, the increase in diseases that generate a state of immunosuppression such as cancer (in addition to the effects of medical treatment as chemotherapy, radiotherapy, or transplants) generate a greater susceptibility to diseases associated with infectious agents [30]. The presence of concomitant diseases can also be a factor that increases the recurrence of diseases such as tuberculosis, common in patients with HIV [38,39].

\subsection{Environmental Health}

As has been mentioned, the high prevalence of food insecurity in the population has effects on access to quality and quantity food, which generates deficiencies in micronutrients and macronutrients that are necessary for the body, in addition to performing its biological functions, can defend against viruses, bacteria and other known and emerging toxic agents.

\subsubsection{Air Pollution and Its Role during the Coronavirus Pandemic}

In recent decades, air quality has deteriorated worldwide, part of this is due to atmospheric pollution, which has increased due to urbanization, the use of cars, factories, the inefficient combustion of biomass among others, becoming thus in the main environmental risk for health [40].

Air pollution is the emission into the atmosphere of toxic elements, generated by human activities. Air pollution is a serious health problem, criteria pollutants such as particulate matter (PM), Sulfur Dioxide $\left(\mathrm{SO}_{2}\right)$ and Nitric Oxide derivatives (NOx) have been associated with the development of cardiovascular and pulmonary diseases. [41], both in children and adults [42,43]. Among the main associated diseases are cerebrovascular accidents, lung cancer, respiratory infections, ischemic heart disease, chronic and acute neuropathies.

During the SARS-CoV-2 epidemic, because of the confinement, in many countries the air pollution data have been significantly reduced, which has undoubtedly benefited the 
population in terms of the quality of the air they breathe. The presence of air pollutants such as particulate material with a diameter smaller than $10 \mu \mathrm{m}$ (PM10) and with diameter less than $2.5 \mu \mathrm{m}$ (PM2.5) and Nitrogen Dioxide $\left(\mathrm{NO}_{2}\right)$ can influence the epidemiology of SARS-CoV-2 infection, as shown by studies in Italy, where the average concentrations in the last 4 years of $\mathrm{NO}_{2}, \mathrm{PM} 2.5$ and PM10 with the number of days that exceeded regulatory limits for $\mathrm{O}_{3}$ and PM10 were significantly correlated with COVID-19 cases [44]. This and other studies have suggested that chronic exposure to air pollution may have a favorable context for the spread and virulence of SARS-CoV-2 [45].

Confinement, reduction in manufacturing and industrial activities benefited air quality, reducing the emission of pollutants into the atmosphere [46], which could have beneficial health effects. However, during a pandemic of the magnitude reached by SARS-CoV-2, this effect may be of limited utility. Pollutants have long-term effects, affecting the respiratory and cardiovascular system, which increases the risk of mortality from COVID-19, so efforts must be redoubled to reduce air pollution and favor the protection of human health and the prevention of the spread of epidemics.

\subsubsection{Water Security}

According to the WHO, about 780 million people around the world lack access to a source of good-quality water and approximately 2.5 billion people lack access to adequate sanitation. These deficiencies represent one of the main environmental risks, since various pathogenic microorganisms are transmitted through the environment and reach the population through the contamination of the water used for drinking [47].

In Mexico, 8,411,920 households ( $25 \%$ of the total population) have limited access to drinking water. Of the 2457 municipalities and delegations in our country, only 827 (34\%) have wastewater treatment [48]. The scenario for Mexico involves various sociodemographic and climatic factors, such as urbanization, industrialization, and the improvement of the standard of living, as well as the high demand for the use of natural resources such as water, soil, air, solar energy, among others.

On the planet, an estimated 842,000 deaths are generated annually due to the lack of safe water and poor sanitation and hygiene, [49] and include 361,000 deaths of children under 5 years of age, most of them in countries of low income [50]. Human health depends on a wide variety of factors, among which the environment is very important. According to some estimates, environmental factors are responsible for between 25 and 33\% of the global burden of the disease, primarily affecting the population under five years of age. Not having access and availability of good-quality water can put the health and integrity of the population at risk. Various health risks have been detected when using water, for example, for the following activities: consumption of food and beverages, recreation, exposure to wastewater, as well as medical uses. Furthermore, the main health risks are related to pollution; this can be microbiological (bacteria, viruses, and parasites); chemical (metals, pesticides, disinfection by-products, etc.) and related to toxins (toxins produced by algae, etc.). Under this same context, in the demand for water resources, approximately $60 \%$ of the world population may suffer physical water shortage by the year 2025 [51]. For example, a total of 288 large basins in which the water resource is overexploited in Europe, North Africa, the Middle East, India, China, and North America. In the case of Mexico, practically all the basins in the center and north of the country, in addition to the Lerma river basin and Valle de Mexico, have high levels of exploitation or overexploitation [52,53].

The various industrial activities generate polluting wastewater and, together with the increase in population and water scarcity, are the main factors driving the reuse of untreated wastewater for irrigation and other uses in many poor countries, which represents a significant threat to world food security. In several countries, the increased demands for water from a growing population are seen as the main driving forces behind the reuse of wastewater for urban and irrigation uses to meet their needs and food.

Wastewater come from mainly the amalgamation of industrial, domestic, commercial, and agricultural activities. In many countries, such as Mexico, poor farmers often depend 
on wastewater for their crops [54]. The farmers are vulnerability do not know the significant associated health and safety hazards environment [54,55]. Furthermore, most countries in the Asia and Africa regions, such as China, India, Pakistan, Egypt, and Morocco, continue to use untreated wastewater as a source of essential nutrients [56] for the production of food crops [57].

In Mexico, according to the National Water Program (In Spanish CONAGUA) and based on the reform of Article $4^{\circ}$ of the Political Constitution of the United Mexican States (8 February 2012), it is mentioned that "All Mexicans have the right to access, disposition and sanitation of water for personal and domestic consumption in sufficiency, healthy and affordable" [58]. This reform establishes the participation of the three levels of government (municipal, State, and federal government) and of society itself to guarantee this right. However, Mexico has a water deficit and, according to the National Water Commission [59] in Mexico, only 50\% of municipal and industrial wastewater is treated. In rural communities, the installation of wastewater treatment plants is hardly difficult considered, in such cases the communities tend to discharge their wastewater in open areas such as lakes, ponds, rivers or the sea. These discharges in turn become a source of infections, also affecting the native flora and fauna of the ecosystem. Faced with this situation, the installation of wastewater treatment plants and the search for options to have a greater quantity of quality water is pertinent. One of the situations in which there is an insufficient number of treatment plants is due to the high cost they involve in terms of design, installation, operation (maintenance) among which the high energy consumption required. Many municipalities mainly in rural populations do not have economical access to the technology for treatment the greater the demand for water, the more wastewater will be generated. One of the greatest water challenges in many countries on the planet and in Mexico is quality.

In 2015 , the industry treated $70.5 \mathrm{~m}^{3} / \mathrm{s}$ of wastewater, in 2832 plants in operation nationwide. Several treatment systems only implement primary and secondary treatments, these levels being insufficient, since a series of recalcitrant compounds remain without removal, and not regulated as pesticides, drugs, antibiotics, among others, generically called emerging pollutants. Only 34\% of the 2457 municipalities and delegations in the country have a wastewater treatment service [60]. Most of the untreated wastewater discharges are made in rivers and streams, canals and on the ground or ravines. As a result, the water bodies in Mexico have a very low quality, not only considering the basic parameters with which National Water Commission classifies the quality of water bodies, but also many other non-regulated parameters that come from discharges of industrial water or water agricultural drains.

In addition to the above, water pollution from industries such as the steel industry, tanneries, chemicals, among others, generate wastewater discharges with metal content such as chromium, lead, cadmium or mercury constitutes a great risk for human beings, it must comply with existing standards to effectively protect health.

A total of $71 \%$ of the surface of planet Earth is covered by the ocean; this portion contains $97 \%$ of the planet's water, and the remaining $3 \%$ is present in rivers, lakes, glaciers, and polar caps and in the atmosphere as water vapor. The global ocean stores carbon dioxide 50 times more than the planet's atmosphere, in addition, it carries heat from the area of the equator to the poles, which regulates the climate and weather patterns. All life on the surface depends on the health of the ocean [61].

On 20th century, oxygen concentrations have decreased by $2 \%$ (77 billion tons) in the open ocean and more than 500 sites in coastal waters have reported oxygen concentrations $\leq 2 \mathrm{mg} / \mathrm{L}$. The expansion of areas with no or little oxygen affects terrestrial and aquatic ecosystems. The cause of water and land pollution is attributed to human action [62].

The quality of water, adequate sanitation and the application of good hygiene practices carry health benefits, especially in sanitary crises such as that triggered by SARS-CoV2. The $\mathrm{WHO}$ has emphasized that the provision of safe water, sanitation and hygienic conditions are essential to protect health COVID-19 outbreak [63]. In healthcare settings, 
proper water management is vital protect staff and caregivers against the risks of infection (washed hand) [64,65].

\subsubsection{Waste Management during the Coronavirus Pandemic}

According to figures from the Ministry of Environment and Natural Resources (SEMARNAT) in Mexico 102,895 tons of waste are generated daily, of which $83.93 \%$ are collected and $78.54 \%$ are carry to disposal sites, recycling only $9.63 \%$ of the waste generated [65].

A total of 53.1 million tons of Urban Solid Waste (USW) is generated (each inhabitant generates approximately $1.2 \mathrm{~kg}$ of garbage per day or $438 \mathrm{~kg}$ per year). In the case of coronavirus patients who remain convalescent at home, since April 1 the Government of Mexico City generated recommendations on the correct separation of waste, to reduce the transmission of COVID-19 in the population of the city de Mexico and protect cleaning workers by separating recyclable inorganic, non-recyclable inorganic, sanitary and organic waste.

SEMARNAT has also estimated that patients infected with COVID-19 in Mexico have generated about 350 tons of biological-infectious waste of those classified as nonanatomical, among which are disposable materials such as gloves, gowns, goggles and face masks. Each coronavirus patient produces an average of 2 to $2.2 \mathrm{~kg}$ of waste considered dangerous per day. In accordance with the "Official Mexican Standard NOM-087-ECOLSSA1-2002 (Environmental Protection-Environmental Health-Bio-infectious Hazardous Waste)", non-anatomical biological-infectious waste can be incinerated or chemically treated to eliminate its danger, and subsequently be deposited in sanitary landfills for urban solid waste. However, it is not yet known what environmental repercussions and health impacts that household waste will have [66].

The WHO has recommended to countries for adequate waste management during the COVID-19 pandemic, since the incorrect handling of such a volume of products can cause "a rebound effect", both on people's health and the environment [67].

\subsubsection{Impact of Food Production}

In Mexico, agriculture has formed a close relationship with nature, due to ancient cultures and because it is a territory with a wide biodiversity where $15.4 \%$ of the species in the world are found in Mexico. However, agro-industrialization has caused land degradation, generated an increase in greenhouse gases, water pollution, loss of soil and, therefore, of biodiversity. Monocultures create a vulnerable food system. With this, the contamination of the water with the abuse of pesticides and the use of nitrates and phosphates with impacts on the loss of biodiversity was substantially increased and a 25 to $30 \%$ of greenhouse gas emissions. Record maize harvests were recorded between 2017 and 2018, 5\% more than in previous years, but this did not mean a food improvement in the population, given that it is the period with the highest registration of hungry people in the world and in the story: one billion people without food [68]. However, climate change and extreme events have affected food security due to low crop and agricultural yields. Currently between 25 and $30 \%$ of the food produced is lost or discarded. It warns then about the various consequences that inaction in the face of the climatic phenomenon that leads to a $2{ }^{\circ} \mathrm{C}$ increase in the planet's temperature would entail: the effects would be more costly than applying mitigation and adaptation measures early [69].

This pandemic situation reveals the systemic nature of our world: human, animal and ecological health are closely linked to food security. COVID-19 is a wake-up call for humanity to rethink our capitalist and highly consumerist mode of development with the ways in which we relate to nature. The times demand a comprehensive response to the current crisis, where the root causes behind the already apparent fragility and socioecological vulnerability of our world are addressed. For decades, many agro-ecologists have denounced the impacts of industrial agriculture on human health and ecosystems. Large-scale monocultures occupy about $80 \%$ of the 1.5 billion hectares devoted to agri- 
culture worldwide. Due to their low ecological diversity and genetic homogeneity, they are highly vulnerable to weed infestations, insect invasions and disease epidemics, and recently to climate change. To control pests, about 2.3 billion $\mathrm{kg}$ of pesticides are applied each year, less than $1 \%$ of which reaches the target pests [70]. Most end up in the soil, air, and water systems, causing environmental and public health damage estimated at more than USD 10 billion a year in the United States. These figures do not include instances of pesticide poisoning in people, which worldwide, affect approximately 26 million people annually $[70,71]$. These calculations also do not consider the costs associated with the acute and chronic toxic effects caused by pesticides via residues in food. There are several works that have reported on how industrial livestock confined in "feedlots" are particularly vulnerable to devastation by different viruses such as avian flu and influenza. Large farms that have tens of thousands of chickens or thousands of pigs in the name of efficient protein production create an opportunity for viruses such as influenza to mutate and spread. The practices in these industrial operations (confinement, respiratory exposure to high concentrations of ammonia, hydrogen sulfide, etc., emanating from the waste) not only leave animals more susceptible to viral infections, but can also trigger the conditions in which pathogens can evolve into more virulent and infectious virus types. These ever-changing viruses give rise to the next human pandemic. This, linked to the situation, worsens as biodiverse agro-landscapes in which crops are surrounded by areas of natural vegetation, are being replaced by large areas of monoculture that cause deforestation and the appearance of diseases.

\subsection{Economic Factors}

Food security is undoubtedly one of the great challenges that governments face. It is proposed that the population have nutritious, culturally appropriate, and ecologically sustainable food. However, social, and economic strategies have not shown significant progress. According to data from the Human Development Report of the United Nations Development Program (UNDP) 2019, 17.6\% of the Mexican population is below the national food poverty line.

Faced with such a scenario, the role played by the formulation of policies around international trade stands out, which has favored the establishment of a corporate agrifood regime, which dictates the rules for the production and distribution of food at a global level. This has shown the deepening and the impacts of the international division of labor around transnational complexes of primary products [72], turning them into a commodification dynamic.

In the Mexican case, these effects were manifested with greater force after the entry into force of the North American Free Trade Agreement (NAFTA) in 1994, which implied structural reforms aimed at agriculture and consequently changes in the productive structure and modifications in the cropping pattern; the importation of large volumes of cheaper food increased, resulting in the displacement of small national agricultural producers, and raising large transnational companies [73].

According to the Agroindustry Atlas 2019 of the Heinrich Böll Foundation, fifty business groups invoice $50 \%$ of world food production sales. Among them are Unilever, Nestlé, Kraft-Heinsz, Mars, Sigma, Kellogg, Pepsico. As Hernández and Martínez write, "Several of them operate in Mexico, with farms for chickens, pigs or cattle. To these we must add Mexican transnational companies such as Gruma, Bimbo and Bachoco". More than two decades after the implementation of NAFTA, these large agri-food companies have obtained extraordinary profits but leaving serious damage to health and the environment in their wake [73].

Regarding health, the high consumption of bottled beverages and ultra-processed products in Mexico has increased non-communicable diseases and obesity rates, which are considered a cause of death. According to the Organization for Economic Cooperation and Development (OECD), diabetes and obesity are the great challenges of the health system in Mexico. 
Mexico has one of the highest obesity rates in the OECD, which implies a reduction in life expectancy by more than four years during the next thirty years. Obesity-related diseases are projected to have a negative impact on gross domestic product (GDP) between 2020 and 2050 [74]. Without the application of cost-effective measures and interventions for the prevention and control of patients with obesity, it is estimated that the direct costs for 2023 will amount to MXN 184,982 million (about USD 8400 million) [75].

Likewise, the lack of regulation on the use of glyphosate in agriculture has caused a state of alarm, for decades the damage to health that it causes has been scientifically documented, such as: encephalopathies, autism, various types of cancer, malformations, among others. Velázquez [76] has documented the impacts of pesticides on the Zirosto day laborers in Michoacan exposed in the avocado plots and in the black-berry or berry harvest for export.

It is worth mentioning that the demand for so-called berries has increased in the last ten years, which has led to an increase in the production area, an example is the production of strawberries in the State of Michoacán, the number of hectares produced increased from year 2004 to 2017 by $233 \%$. This type of intensive cultivation requires, as we have already mentioned, large areas of land and significant amounts of labor, as well as an intensive use of large volumes of water [76]. It is significant that the state of Guanajuato is the first producer of broccoli in the country and the second producer of asparagus after Sonora and at the same time is one of the states of the Mexican Republic with the highest water stress and with health problems correlated with contaminated water.

These studies show that globalized agricultural employment provides precarious and temporary jobs, also exposing workers to pollutants without any protection, where in many cases, many women are forced to be hired as day laborers in seasonal agricultural productions that they are linked to non-traditional agricultural exports, deepening capitalist relations of production and placing them in a situation of vulnerability, being an easy target for greater exploitation and a greater burden of socio-environmental costs [77].

The current agri-food model in Mexico has not only impacted business growth [73], but also on the health status of Mexicans due to the consumption of non-nutritious foods [74], exposure to toxins [76] and the lack of working conditions [77]. The health and socioenvironmental impacts derived from the agri-food regime and, in general, from extractivist policies urge us to rethink social development policies. The health crisis that we are experiencing due COVID-19 made visible the logic of care and to discussion about the jobs least valued, the most despised and the least protected [78], and the dismantling of health systems. This health crisis has also shown something that economic policy makers seem to ignore: the fact that unlimited growth cannot be possible in an ecological system subject to biophysical limits [79].

Therefore, thinking about alternatives implies questioning the current production model and the implicit destruction of nature that it brings with it. It also implies the questioning of an idea of society marked by individual interest. Additionally, it raises the dichotomy that arises between human beings and nature. We need a policy that is committed to planetary life. Specific actions are urgently needed such as: the elimination of pesticides, a law that declares the country free of transgenic crops, the dismantling of the agri-food corporations' system, it is necessary to promote local self-sufficiency and support small producers.

Agroecology is a tool that can serve in the construction of alternatives that bet on social and environmental well-being, the adoption of this has been useful as an instrument in the construction of food sovereignty and as a tool for struggle, defense, (re)configuration and transformation of disputed lands and territories into peasant territories [80]. It is necessary to lay the foundations to formulate actions with an ethical sense of life and that have socio-environmental justice as a horizon. 


\subsection{Regulatory Framework}

On 13 October 2011, the right to nutritious, sufficient, and quality food was integrated into the constitutional text. In 2012, only a few months later (on 8 February), the right to water and a healthy environment was clearly accepted in an associated way. Since 1999, the human right to an adequate environment was integrated into the fourth constitution, its association with the other economic and social rights described here is perfectly delineated. The Magna Carta in its first third, fourth, fifth and sixth paragraphs makes it clear in this way: Everyone has the right to nutritious, sufficient, and quality food. The State will guarantee it. Everyone has the right to health protection. Damage and environmental deterioration will generate responsibility for whoever causes it in terms of the provisions of the law. Everyone has the right to access, disposal and sanitation of water for personal and domestic consumption in a sufficient, healthy, acceptable, and affordable way. The State will guarantee this right, and the law will define the bases, supports and modalities for the access and equitable and sustainable use of water resources, establishing the participation of the Federation, the federative entities, and the municipalities, as well as the participation of the citizens to the achievement of said purposes (Article $4^{\circ}$ of the Political Constitution of the United Mexican States-CPEUM) [81].

Given this, a complex institutional panorama is proposed for coordination based on the design of the Mexican State where responsibility corresponds not only to the Federal Government (through various secretaries of State, such as the Ministry of Agriculture and Rural Development, the Ministry of Welfare or Ministry of the Environment and Natural Resources), if not to the state and municipal governments, in addition to adding in a democratic context the importance of the participation of society, for which the state governments must ensure [82]:

- Respect. The non-existence of barriers for the population to obtain food, access to water and a healthy environment. The same to avoid interventions so that society can materialize its own mechanisms that help and complement the action of the State.

- To protect. Neither companies nor individuals must not deprive people of access to food, water, and a healthy environment, nor must they affect the possibilities of future generations to access it. The same can offer or advertise "goods" that may be detrimental to health, proper nutrition or that affect the environment.

- Perform or facilitate. The actions or policies must seek to strengthen access to food, water, and a healthy environment for the entire population, even when a group or a person is incapable, and in that sense, everything institutionally and humanly possible must be done to achieve this. The case of people who have been victims of natural or human catastrophes such as wars, economic or health crises is highlighted.

The global health emergency due to COVID-19 in the world puts the responsibility of the Mexican State in matters of food, water, and a healthy environment at a new crossroads from 2020 and onwards, and makes it necessary for this institutional framework to be consolidate with policy instruments that allow their urgent articulation [1,17]:

The 'new normal' in terms of public policies that ensure the food-water-environment triad leads us to reflect on the need for a change in the state-society relationship. The role of governments (of the three orders, but with an emphasis on local ones) becomes central due to their ability to make binding not only regulations, but also to materialize collective action of different actors that require collaboration for greater commitment and effectiveness of all actions undertaken.

A vision focused on the regional level (in States and municipalities) is essential, since inequalities are detected at the territorial level, and economic, social, and even cultural dynamics acquire their own forms and weigh at that level of social interaction.

The COVID-19 pandemic will be mitigated, in addition to medical advances in its treatment (beyond the possible vaccine), health for successful management and low infection rates, with actions that enable sustainable social development that emphasizes in equitable, fair, and adequate access to food, clean water and care for the environment (Figure 3) [81]. 

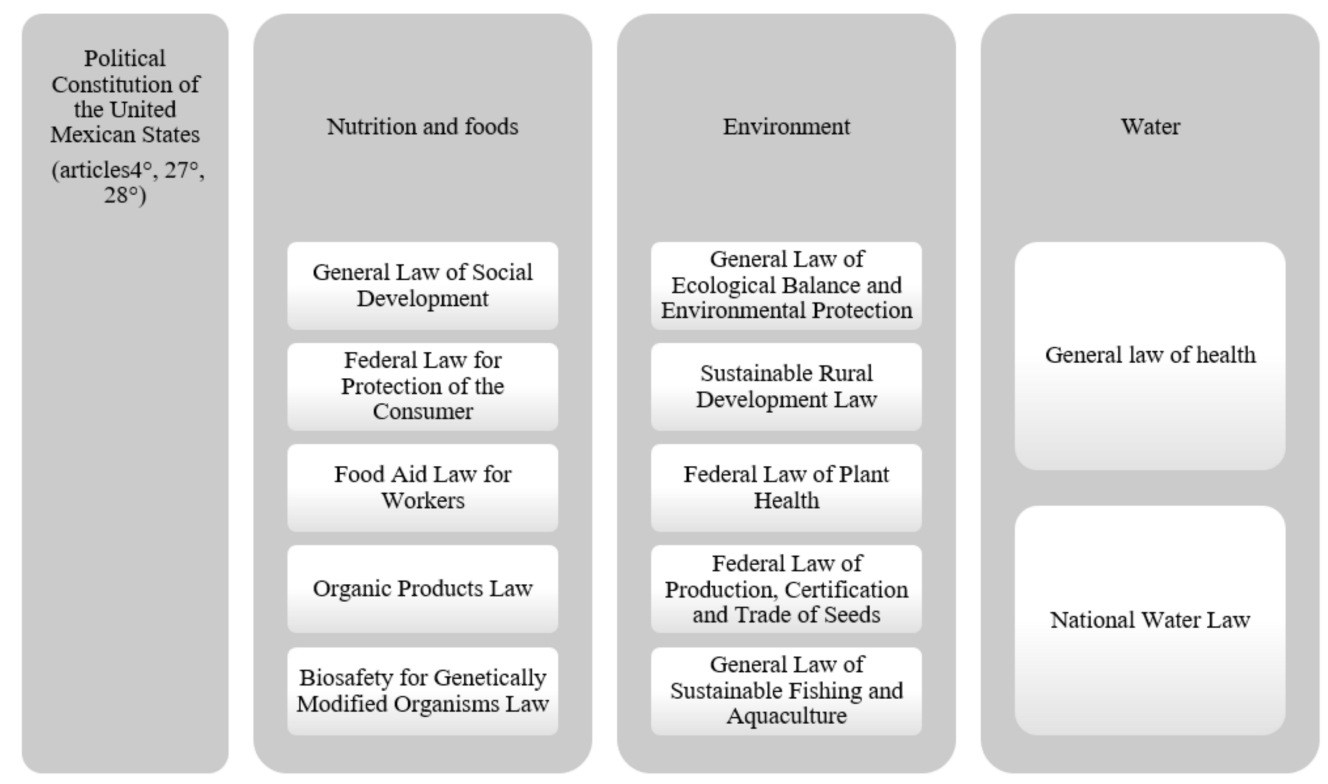

Figure 3. Representation of articles $4^{\circ}, 27^{\circ}$ and $28^{\circ}$ of Political Constitution of the United Mexican States [81].

\section{Lessons Learned from Food Safety, Environmental Health, and the Economy in Mexico}

Guaranteeing a right to health is achieved when the governments generate the conditions to achieve healthy lifestyles in the population. In this case, Mexico signed (like other countries) the commitment to comply with the Agenda of the Sustainable Development Goals, but in accordance with the latest report generated by FAO shows that during COVID-19 contingency increased the levels of child malnutrition, obesity in adults and anemia in women as well as climatic damage; this makes it difficult to eliminate hunger, all forms of malnutrition and poverty [83]. It is known that a person with diabetes spends $30 \%$ of their income on their treatment. These figures have been exacerbated as part of the impacts caused by COVID-19, mainly in the population that was already vulnerable and the population that was on the poverty line or with health problems has been added. In addition to this, the closure of schools, businesses, loss of employment have contributed to the increase in food insecurity and exorbitant health conditions of those who were previously at risk [84], which complicates compliance with international agendas in matter of the right to health and food.

One of the lines of action and intervention to this health and climate crisis is a systemic approach such as agroecology that, at this time of the coronavirus pandemic, can contribute to integrate a link between agriculture and health [69]. Agroecology has gained much attention in the last three decades as the basis for the transition to agriculture that would not only provide rural families with significant social, economic, and environmental benefits, but would also feed the urban population in an equitable and sustainable way. There is an urgent need to promote new local and sustainable food systems to ensure the production of sufficient, healthy, and affordable food for a growing urbanized human population. The agricultural system based on agroecological principles has the advantage of exhibiting high levels of diversity and resilience while offering reasonable yields and ecosystem services. Agroecology proposes restoring the landscapes that surround the farms, which enriches the ecological matrix and its services such as natural pest control, water, and soil conservation, etc. Therefore, in this scenario, the use of efficient eco-technologies that are economically viable is a vital option of urgent application. From the same perspective, one of the advantages that agroecology offers are that it contemplates locally producing a large part of the food necessary for rural and urban communities, particularly in a world threatened by climate change and other contingencies, such as pandemics. However, it must be 
emphasized that support is needed to amplify agroecology to optimize, restore and improve the productive capacities of small local and urban farmers. Successful local agroecological initiatives must be widely disseminated through farmer-to-farmer pedagogical strategies, the creation of agroecological lighthouses, the reactivation of traditional systems and the reconfiguration of entire territories under agroecological management. To improve the economic viability of these efforts, equitable local and regional market opportunities must also be developed, governed by the principles of solidarity economy. At this point, the role of consumers is key if they understand that eating is an ecological and political act, so that when they support local farmers, rather than the corporate food chain, they create socio-ecological sustainability and resilience. This does not lead to reflect on the fact that ecosystems sustain economies and even health; but economies do not sustain ecosystems. COVID-19 reminds us that disrespectful treatment of nature including the biodiversity of plants and animals has consequences, and when they are harmed, ultimately, so are humans. This current crisis caused by COVID-19 also offers an opportunity for humanity to reflect on the impact humans caused on the planet and lead us to lay the foundations of a new world and softer ways of interacting and respecting nature with its own natural resources.

Derived from this analysis where, based on the evidence, an increase in the levels of poverty in the world and, therefore, of food and nutritional insecurity is observed, the economic impacts will be even greater; this is coupled with a poor quality of life [3]. In Mexico and in the world, increasing levels of obesity are causing a greater development of diabetes, hypertension, dyslipidemia and especially infectious diseases; this latter point is due to the inflammatory component that it entails with the elevation of cytokines that are part of an immune system that requires that people have adequate nutrition (foods that provide them with vitamins, minerals, proteins, essential fats in quantity and quality). Having a metabolic disease plus a poor diet, and adding a stressor, is where health vulnerability and getting sick increased the cost of health [85].

The COVID-19 pandemic should teach governments and decision-makers lessons, as is happening so far in Mexico with reforms to the Food Labeling Law approved in March 2020, the Reform in Oaxaca to prevent children access to unhealthy food or foods of poor nutritional quality [86], as well as other actions in health matters, are steps to advance in accordance with the Political Constitution of the United Mexican States in its 4th article that mentions the right to health, to healthy eating, access to drinking water and a healthy environment, mainly.

Therefore, a proposal to promote food security would be from the following questions and actions:

How do we best define the problem of food insecurity in developed nations?

What have we learned from actions taken to date?

What works and what does not?

A lack of individual rights and guarantees, actions from the government to enforce and apply human rights in health.

Regulate the industry to generate more responsible food and production practices with the integration of sustainable policies and codes of ethics.

Governments must invest and rely on Science and Technology to allow access to drinking water treatment and fulfill the right to water.

Regulate and apply the law of natural resources that are part of health protection and integrate new paradigms and economic approaches. This current economic model must be reviewed and adapted to contain the problems of contamination and deterioration to health, the environment and even the economy itself derived from the COVID-19 pandemic.

The COVID-19 pandemic should teach governments and decision-makers lessons, as is happening so far in Mexico with reforms to the Food Labeling Law approved in March 2020, the Reform in Oaxaca to prevent access to children processed foods or foods of poor nutritional quality [86], as well as other actions in health matters, are steps to advance in accordance with the Political Constitution of the United Mexican States in its 4th article 
that mentions the right to health, to healthy eating, access to drinking water and a healthy environment, mainly.

For Mexico, the current reform to the General Health Law, human rights, the advance to the decree for the reduction in Glyphosate, the approval of the Food Labeling Law in March 2020 and the reform in the State of Oaxaca on the protection of access to industrialized food for boys and girls.

Public prevention and self-care policies are needed. The COVID-19 pandemic has reflected a poor level of schooling and education, of appropriating science and technology.

What actions or policy levers show promise?

Health policies should continue to be updated and linked to policies on education and access to science and technology. Access to healthy and safe environments requires a network of actors (Figure 4). Greater integration of academics and researchers to join the legislative work to advance to protect food production, prevent its waste, promote agroecological practices, access to quality education, companies responsible for the health of their consumers and workers, which generates a sustainable economy.

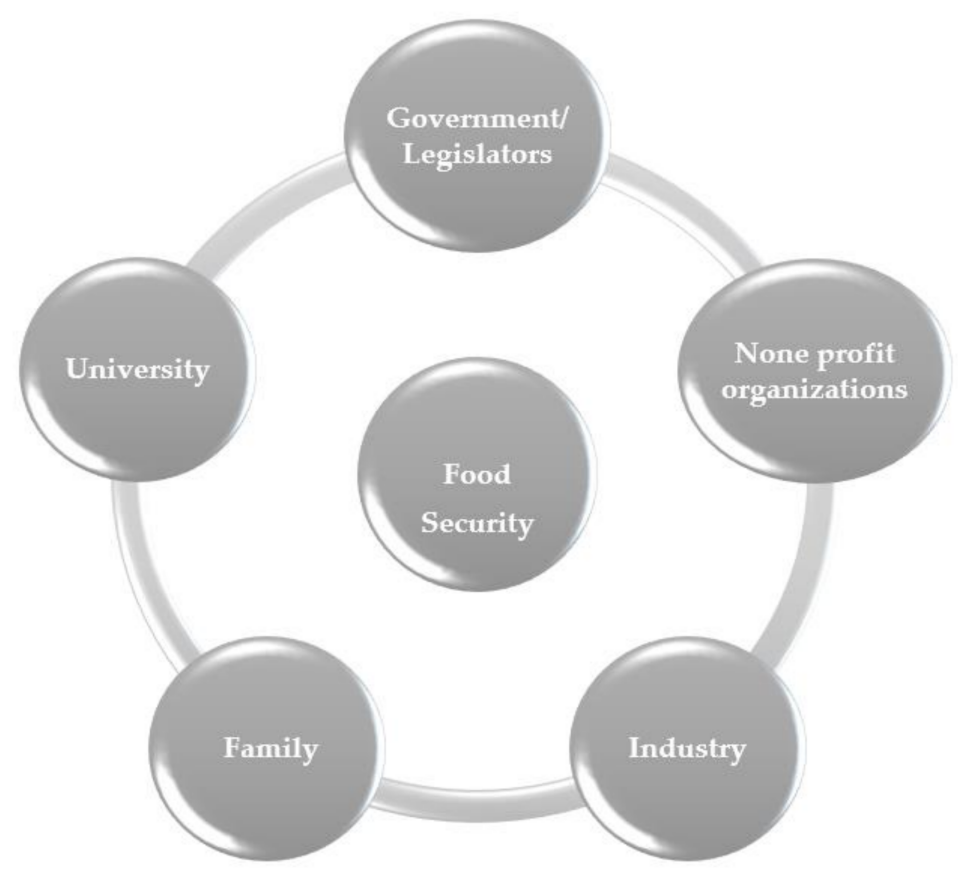

Figure 4. Network of actors to face food insecurity problems.

\section{Conclusions}

The economic impacts have diminished attempts to eradicate hunger and food insecurity) as well as poverty as global goals. Food insecurity requires a network of actors and intersectoral, inter-institutional work to address it now from the complexity of a pandemic. Therefore, the purpose of this review is to present a national panorama (Mexico) that has similarities to the situation that exists in the world on the challenges and opportunities for food security, environmental health, and the economic model in Mexico and to derive proposals from these experiences and lessons learned for decision makers, academics, civil society organizations, and business groups. Regarding the economic activities that compete with food security, the primary sector contributes 3.1\% to the gross domestic product (GDP) of our country ( $2 \%$ agriculture and $1 \%$ livestock, $0.1 \%$ for forestry and fishing activities, respectively). However, also from these activities products are derived for the food and beverage and tobacco industry, with which their economic importance becomes relevant, achieving an increase of up to $7.5 \%$ [13]. For the purposes of the subject dealt with in this work in terms of the Mexican legal framework to understand the economic, social, and cultural rights associated with health, the environment, water, and food, we must 
speak of the fourth constitutional article. A regulatory framework should consider for its design interventions through public policies that aim to reduce the limitations of access to food. It is essential to understand the market conditions that influence the generation of differences in access to food [13].

Therefore, food security and the economic crisis represent an indispensable transition in the Era of COVID-19. Studies are needed to explore and integrate the impacts on food management and the economy in this Era. The economic system has generated environmental impacts (water, air, soil), and human health problems such as high rates of overweight worldwide. Mexico ranks first in obesity, derived from the overexploitation of natural resources. Therefore, the objective of this work was to analyze the impacts on food safety, environmental health, and the economy in Mexico, before and during the contingency due to COVID-19, and with it, integrate the lessons learned. Results: A model was generated based on the lessons learned from this contingency, integrating food safety, environmental health, and the economy, where the design and promotion of public policies (health, environment, and economy) are induced. As well as migrating to a health prevention system and an agroecological model. From a multidisciplinary and intersectoral intervention perspective that should be between government, academics, researchers, civil society organizations, business groups and the citizens themselves by reforming and enforcing the right to enjoy adequate food and a healthy environment. Faced with the era of COVID-19, the lessons learned should promote a sustainable life transition towards this new reality and focus on promoting an innovative and ethical culture of generating an economy, with a gender balance, resilience to climate change, the transparent management of technology and a priority in health, and this will lead to advances in the population's food security.

Author Contributions: Design, R.M.-T.; data collection, R.M.-T.; statistical analysis, R.M.-T.; writing, R.M.-T., A.C.-C., E.C.-V., M.H.-L., A.C.-O., A.S.-M., B.L.-S.; K.M.-J., O.J.-G., M.M.-P. and S.L.-B.; Editing, R.M.-T., A.C.-C. and M.H.-L.; Analysis, A.C.-C., E.C.-V., M.H.-L., A.C.-O., A.S.-M., B.L.-S.; K.M.-J., O.J.-G., M.M.-P. and S.L.-B. All authors have read and agreed to the published version of the manuscript.

Funding: This research received no external founding.

Informed Consent Statement: Not applicable.

Conflicts of Interest: The authors declare no conflict of interest.

\section{References}

1. Hua, J.; Shaw, R. Corona virus (COVID-19) infodemic and emerging issues through a data lens: The case of China. Int. J. Environ. Res. Public Health 2020, 17, 2309. [CrossRef]

2. Johns Hopkins University (JHU). COVID-19 Dashboard by the Center for Systems Science and Engineering (CSSE). Available online: https: / / coronavirus.jhu.edu/map.html (accessed on 5 September 2020).

3. Shamah-Levy, T.; Vielma-Orozco, E.; Heredia-Hernández, O.; Romero-Martínez, M.; Mojica-Cuevas, J.; Cuevas-Nasu, L.; SantaellaCastell, J.A.; Rivera-Dommarco, J. Encuesta Nacional de Salud y Nutrición 2018-19: Resultados Nacionales. Cuernavaca, Mexico: Instituto Nacional de Salud Pública. 2020. Available online: https:/ / ensanut.insp.mx/encuestas/ensanut2018/doctos/informes/ ensanut_2018_presentacion_resultados.pdf (accessed on 6 June 2021).

4. Leyva Trinidad, D.A.; Pérez Vázquez, A. Pérdida de las raíces culinarias por la transformación en la cultura alimentaria. Rev. Mex. Cienc. Agrícolas 2015, 6, 867-881. [CrossRef]

5. FAO. El Estado Mundial de la Agricultura y la Alimentación. Available online: http://www.fao.org/3/i3301s/i3301s.pdf (accessed on 11 June 2020).

6. Lutz, M. Biodisponibilidad de compuestos bioactivos en alimentos. Perspect. Nutr. Hum. 2013, 15, $217-226$.

7. Ministerio de Asuntos Exteriores y de Cooperación; FAO. Seguridad Alimentaria Nutricional, Conceptos Básicos. Proyecto Food Facility Honduras. 2011. Available online: http:/ /www.fao.org/3/at772s/at772s.pdf (accessed on 10 February 2021).

8. FAO. Panorama de la Seguridad Alimentaria y Nutricional en América Latina y el Caribe. 2017. Available online: http: / / www.fao.org/americas/publicaciones-audio-video/panorama/es/ (accessed on 10 February 2021).

9. FAO. El sistema alimentario en Mexico. Oportunidades para el campo mexicano en la agenda 2030 de Desarrollo Sostenible. 2019. Available online: http:/ / www.fao.org/publications/card/es/c/CA2910ES/ (accessed on 12 June 2020). 
10. Monroy Torres, R.; Ruiz González, S.R.; Castillo Chávez, A.M.; Inseguridad Alimentaria y su Asociación con la Obesidad y los riesgos Cardiometabólicos en Mujeres Mexicanas. Nutrición Hospitalaria 2020. Available online: https://www.nutricionhospitalaria. org/articles/03389/show (accessed on 10 February 2021).

11. Consejo Nacional de la Evaluación de la Política de Desarrollo Social. Available online: https://www.coneval.org.mx/rw / resource/coneval/info_public/PDF_PUBLICACIONES/Dimensiones_seguridad_alimentaria_FINAL_web.pdf (accessed on 11 June 2020).

12. FAO. Producción y Manejo de Datos de Composición Química de Alimentos en Nutrición. 1997. Available online: http: //www.fao.org/3/Ah833s07.htm (accessed on 10 February 2021).

13. Sistema de Información Agrícola y Pesquera (SIAP). Tabulados Superficie, Producción y Rendimientos: 1980-2016. Available online: www.siap.gob.mx (accessed on 11 June 2020).

14. FAO. Organic Agriculture. Available online: http://www.fao.org/organicag/oag-glossary/es/ (accessed on 11 June 2021).

15. Figueroa, D. Estado nutricional como factor y resultado de la seguridad alimentaria y nutricional y sus representaciones en Brasil. Rev. Salud Pública 2004, 6, 140-155.

16. Rivero, B.; Aliaga, J. Disponibilidad, consumo y utilización biológica de alimentos en Bolivia: Análisis y perspectivas (1990-2030). LAJED 2014, 22, 161-198. [CrossRef]

17. Crespo, M.E.; Pérez, M.M. Un acercamiento a la gestión de la seguridad alimentaria y nutricional desde los gobiernos locales. Rev. Coop. Desarro. 2014, 2, 188-198.

18. NORMA Oficial Mexicana NOM-251-SSA1-2009. Prácticas de Higiene para el Proceso de Alimentos, Bebidas o Suplementos Alimenticios. In Diario Oficial de la Federación; 2008. Available online: https: / / www.dof.gob.mx/normasOficiales/3980/salud/ salud.htm\#: :text=NORMA\%20Oficial\%20Mexicana\%20NOM\%2D251\%2DSSA1\%2D2009\%2C\%20Pr\%C3\%A1cticas,que\%20 dice $\% 3 \mathrm{~A} \% 20$ Estados\%20Unidos\%20Mexicanos (accessed on 12 June 2020).

19. FAO; OMS. Análisis de Riesgos Relativos a la Inocuidad de los Alimentos. Estudio FAO Alimentación y Nutrición. 2007. Available online: http:/ / www.fao.org/3/a-a0822s.pdf (accessed on 12 June 2020).

20. Latham, M.; Nutrición Humana en el Mundo en Desarrollo. FAO. 2002. Available online: http://www.fao.org/3/w0073s/w007 3s00.htm\#Contents (accessed on 12 June 2020).

21. Havelaar, A.H.; Kirk, M.D.; Torgerson, P.R.; Gibb, H.J.; Hald, T.; Lake, R.J.; Praet, N.; Bellinger, D.C.; de Silva, N.R.; Gargouri, N.; et al. World Health Organization Global Estimates and Regional Comparisons of the Burden of Foodborne Disease in 2010. PLoS Med. 2015, 12, e1001923. [CrossRef]

22. WHO. Food Safety. Available online: https://www.who.int/foodsafety/areas_work/foodborne-diseases/ferg_infographics/en/ (accessed on 12 June 2020).

23. Scallan, E.; Hoekstra, R.M.; Angulo, F.J.; Tauxe, R.V.; Widdowson, M.A.; Roy, S.L.; Jones, J.L.; Griffin, P.M. Foodborne illness acquired in the United States-Major pathogens. Emerg. Infect. Dis. 2011, 17, 7-15. [CrossRef]

24. Pires, S.M.; Vieira, A.R.; Perez, E.; Lo Fo Wong, D.; Hald, T. Attributing human foodborne illness to food sources and water in Latin America and the Caribbean using data from outbreak investigations. Int. J. Food Microbiol. 2012, 152, 129-138. [CrossRef] [PubMed]

25. Bartsch, S.M.; Asti, L.; Nyathi, S.; Spiker, M.L.; Lee, B.Y. Estimated Cost to a Restaurant of a Foodborne Illness Outbreak. Public Health Rep. 2018, 133, 274-286. [CrossRef] [PubMed]

26. Harvard Medical School, Brigham; Women's Hospital. Cases in Global Health Delivery. Malnutrition. Available online: https:/ / ghsm.hms.harvard.edu/research/global-health-delivery (accessed on 10 May 2021).

27. National Institutes of Health. Understanding Emerging and Re-emerging Infectious Diseases. In Biological Sciences Curriculum Study; NIH Curriculum Supplement Series; National Institutes of Health: Bethesda, MD, USA, 2007; p. 56.

28. Kuri Morales, P.A.; Guzman Morales, E.; De La Paz-Nicolau, E.; Salas Fernandez, A. Enfermedades emergentes y reemergentes. Gac. Med. Mex. 2015, 151, 674-680.

29. Chidiac, C.; Ferry, T. Emerging infectious agents. Transfus. Clin. Biol. 2017, 23, 253-262. [CrossRef]

30. Coltart, C.E.; Lindsey, B.; Ghinai, I.; Johnson, A.M.; Heymann, D.L. The Ebola outbreak, 2013-2016: Old lessons for new epidemics. Philos. Trans. R. Soc. Lond. B Biol. Sci. 2017, 372, 20160297. [CrossRef]

31. Vu, D.M.; Jungkind, D.; Angelle Desiree, L. Chikungunya Virus. Clin. Lab. Med. 2017, 37, 371-382. [CrossRef] [PubMed]

32. Rojas, M.; Monsalve, D.M.; Pacheco, Y.; Acosta Ampudia, Y.; Ramirez Santana, C.; Ansari, A.A.; Gershwin, M.E.; Anaya, J.M. Ebola virus disease: An emerging and re-emerging viral threat. J. Autoimmun. 2020, 106, 102375. [CrossRef] [PubMed]

33. Zaidi, M.B.; Campos, F.D.; Estrada Garcia, T.; Gutiérrez, F.; Leon, M.; Chim, R.; Calva, J.J. Burden and transmission of zoonotic foodborne disease in a rural community in Mexico. Clin. Infect. Dis. 2012, 55, 51-60. [CrossRef] [PubMed]

34. Canizalez Roman, A.; Velazquez Roman, J.; Valdez Flores, M.A.; Flores Villasenor, H.; Vidal, J.E.; Muro Amador, S.; Guadron Llanos, A.M.; Gonzalez Nunez, E.; Medina Serrano, J.; Tapia Pastrana, G.; et al. Detection of antimicrobial-resistance diarrheagenic Escherichia coli strains in surface water used to irrigate food products in the northwest of Mexico. Int. J. Food Microbiol. 2019, 304, 1-10. [CrossRef] [PubMed]

35. Robins Browne, R.M.; Holt, K.E.; Ingle, D.J.; Hocking, D.M.; Yang, J.; Tauschek, M. Are Escherichia coli Pathotypes Still Relevant in the Era of Whole-Genome Sequencing? Front. Cell. Infect. Microbiol. 2016, 6, 141. [CrossRef]

36. Swaggerty, C.L.; Callaway, T.R.; Kogut, M.H.; Piva, A.; Grilli, E. Modulation of the Immune Response to Improve Health and Reduce Foodborne Pathogens in Poultry. Microorganisms 2019, 7, 65. [CrossRef] 
37. Taylor, L.H.; Latham, S.M.; Woolhouse, M.E. Risk factors for human disease emergence. Philos. Trans. R. Soc. Lond. B Biol. Sci. 2007, 356, 983-989. [CrossRef]

38. Dewey-Mattia, D.; Roberts, V.A.; Vieira, A.; Fullerton, K.E. Foodborne (1973-2013) and Waterborne (1971-2013) Disease Outbreaks-United States. MMWR Morb. Mortal. Wkly. Rep. 2016, 63, 79-84. [CrossRef]

39. OMS. Guías de Calidad del Aire de la OMS Relativas al Material Particulado, el Ozono, el Dióxido de Nitrógeno y el Dióxido de Azufre. Available online: https:/ / www.who.int/phe/health_topics/AQG_spanish.pdf (accessed on 28 June 2020).

40. Anderson, J.; Hundiyil, J.; Stolbach, A. Clearing the Air: A Review of the Effects of Particulate Matter Air Pollution on Human Health. J. Med. Toxicol. 2011, 8, 166-175. [CrossRef] [PubMed]

41. Cortez-Lugo, M.; Ramírez-Aguilar, M.; Pérez-Padilla, R.; Sansores-Martínez, R.; Ramírez-Venegas, A.; Barraza-Villarreal, A. Effect of Personal Exposure to PM2.5 on Respiratory Health in a Mexican Panel of Patients with COPD. Int. J. Environ. Res. Public Health 2015, 12, 10635-10647. [CrossRef]

42. Linares, B.; Guizar, J.M.; Amador, N.; Garcia, A.; Miranda, V.; Perez, J.R.; Chapela, R. Impact of air pollution on pulmonary function and respiratory symptoms in children: Longitudinal repeated-measures study. BMC Pulm. Med. 2010, 10, 62. [CrossRef]

43. Fattorini, D.; Regoli, F. Role of the chronic air pollution levels in the Covid-19 outbreak risk in Italy. Environ. Pollut. 2020, 264, 114-732. [CrossRef] [PubMed]

44. Frontera, A.; Cianfanelli, L.; Vlachos, K. Severe air pollution links to higher mortality in COVID-19 patients: The "double-hit" hypothesis. J. Infect. 2020, 81, 255-259. [CrossRef]

45. Wang, P.; Chen, K.; Zhu, S.; Wang, P.; Zhang, H. Severe air pollution events not avoided by reduced anthropogenic activities during COVID-19 outbreak. Resour. Conserv. Recycl. 2020, 158, 104-814. [CrossRef]

46. UNICEF. Agua, Saneamiento, Higiene y Gestión de Desechos en Relación con el Virus de la COVID-19: Orientaciones Provisionales. Available online: https:/ / apps.who.int/iris/handle/10665/331929 (accessed on 28 June 2020).

47. CONAGUA. Available online: http://www.conagua.gob.mx/CONAGUA07/Contenido/Documentos/elaguaenmexicocaucesyencauces.pdf (accessed on 11 June 2020).

48. Schumacher, L.L.; Huss, A.R.; Cochrane, R.A.; Stark, C.R.; Woodworth, J.C.; Bai, J.; Poulsen, E.G.; Chen, Q.; Main, R.G.; Zhang, J.; et al. Characterizing the rapid spread of porcine epidemic diarrhea virus (PEDV) through an animal food manufacturing facility. PLoS ONE 2017, 12, e0187309. [CrossRef]

49. Organización Mundial de la Salud; War Trauma Foundation; Visión Mundial Internacional. Primera Ayuda Psicológica: Guía para Trabajadores de Campo; OMS: Ginebra, Switzerland, 2012.

50. Martínez, R.; Palma, A. Seguridad Alimentaria y Nutricional en Cuatro Países Andinos: Una Propuesta de Seguimiento y Análisis, 1st ed.; Naciones Unidas: Santiago de Chile, Chile, 2014.

51. Smakhtin, V.; Revenga, C.; Döll, P. Una evaluación global piloto de los requisitos ambientales y la escasez de agua. Water Int. 2004, 29, 307-317. [CrossRef]

52. Gresh, A.; Rekacewicz, P. Planet in Peril: An Atlas of Current Threats to People and the Environment; Earthprint: Birkeland, Norway, 2006.

53. Martínez, A.; Polioptro, F.; Díaz-Delgado, C.; Moeller-Chavez, G. Seguridad hídrica en Mexico: Diagnóstico general y desafíos principales. Ing. Agua 2019, 23, 107-121. [CrossRef]

54. Centro UC, Derecho y Gestión de Aguas. Available online: http://repositorio.ana.gob.pe/bitstream/handle/20.500.12543/3831/ ANA0002332.pdf? sequence=1\&isAllowed =y (accessed on 12 August 2020).

55. Melián-Navarro, A.; Fernández-Zamudio, M.A. Reutilización de agua para la agricultura y el medioambiente. Agua Territ. 2016, 8, 80-92. [CrossRef]

56. Mora, S.G.; Gavi, F.; Tijerina, L.; Pérez, J.; Peña, J.J. Evaluación de la recuperación del nitrógeno y fósforo de diferentes fuentes de fertilizantes por el cultivo de trigo irrigado con aguas residuales y de pozo. Acta Agronómica 2014, 63, 25-30. [CrossRef]

57. Romero-Martínez, M.; Shamah-Levy, T.; Cuevas-NasuIgnacio, L.; Gómez-Humarán, M.; Gaona-Pineda, E.B.; Gómez-Acosta, L.M.; Rivera-Dommarco, J.A.; Hernández-Ávila, M. Diseño metodológico de la Encuesta Nacional de Salud y Nutrición de Medio Camino 2016. Salud Pública Mex. 2017, 59, 299-305. [CrossRef] [PubMed]

58. Cámara de Diputados. LXII Legislatura. Available online: http://www3.diputados.gob.mx/camara/001_diputados/01 2_comisioneslxii/01_ordinarias/002_agua_potable_y_saneamiento/13_marco_juridico/01_constitucion_politica_de_los_ estados_unidos_mexicanos (accessed on 12 August 2020).

59. INEGI. Agua. Available online: https://www.inegi.org.mx/temas/agua/ (accessed on 12 August 2020).

60. Gobierno de Mexico. Available online: https://www.gob.mx/semarnat/articulos/cambio-climatico-impacta-la-seguridadalimentaria-por-bajos-rendimientos-agricolas-y-ganaderos (accessed on 12 August 2020).

61. Lloyd-Smith, M.I.J. Ocean Pollutants Guide: Toxic Threats to Human Health and Marine Life. 2018. Available online: https: //ipen.org/sites/default/files/documents/ipen-ocean-pollutants-v2_1-en-web.pdf (accessed on 12 August 2020).

62. Arreguin Ruiz, J. Zonas económicas de Mexico. 2019. Available online: https://asnews.mx/noticias/zonas-economicas-demexico (accessed on 11 June 2020).

63. WHO. Normas Básicas de Higiene del Entorno en la Asistencia Sanitaria. Ginebra, Organización Mundial de la Salud. Available online: http:/ / www.who.int/water_sanitation_health/publications/ehs_hc/es / (accessed on 28 June 2020).

64. WHO. Guidelines on Hand Hygiene in Health Care. Ginebra, Organización Mundial de la Salud. Available online: https://www. who.int/gpsc/5may/tools/9789241597906/en/ (accessed on 28 June 2020). 
65. SEMARNAT. Secretaría de Medio Ambiente y Recursos Naturales. Información sobre residuos sólidos urbanos. Available online: https:/ / www.gob.mx/semarnat/acciones-y-programas/residuos-solidos-urbanos-rsu (accessed on 28 June 2020).

66. NORMA Oficial Mexicana NOM-087-ECOL-SSA1-2002. Protección Ambiental—Salud Ambiental—Residuos Peligrosos BiológicoInfecciosos-Clasificación y Especificaciones de Manejo. Available online: http://www.salud.gob.mx/unidades/cdi/nom/08 7ecolssa.html (accessed on 28 August 2020).

67. ONU Mexico. Cómo ha de ser la Gestión de Residuos Durante la Pandemia del Coronavirus? Mexico. Available online: http:/ / coronavirus.onu.org.mx/como-ha-de-ser-la-gestion-de-residuos-durante-la-pandemia-del-coronavirus (accessed on 22 July 2020).

68. Eguillor, P. Pérdida y Desperdicios de Alimentos, 1st ed.; ODEPA: Santiago de Chile, Chile, 2017.

69. Valentín, V.; Rosset, P.M.; Zamora, K.; Giraldo, O.F.; Rocheleau, D. Agroecology La Via Campesina, I. The symbolic and material construction of agroecology through the dispositive of "peasant-to-peasant" processes. Agroecol. Sustain. Food Syst. 2019, 43, 872-894. [CrossRef]

70. Altieri, M.A.; Nicholls, C.I.; Centro Latinoamericano de Investigaciones Agroecológicas. La Agroecología en Tiempos del COVID-19. Available online: https:/ / www.clacso.org/la-agroecologia-en-tiempos-del-covid-19/ (accessed on 24 July 2020).

71. Las Pérdidas y el Desperdicio de Alimentos en el Contexto de Sistemas Alimentarios Sostenibles. Available online: http: / / www.fao.org/3/a-i3901s.pdf (accessed on 20 July 2020).

72. McMichael, P. Regímenes Alimentarios y Cuestiones Agrarias, 1st ed.; Miguel Ángel Porrúa: Ciudad de Meéxico, Mexico, 2015.

73. Hernández, J.; Martínez, D. Efectos del cambio de precios de garantía a procampo en precios al productor, sin incluir efecto de importaciones. Rev. Fitotec. Mex. 2009, 32, 153-159.

74. OCDE. Combatir la Obesidad Impulsaría la Economía y el Bienestar. Available online: https://www.oecd.org/centrodemexico/ medios/combatirlaobesidadimpulsarialaeconomiayelbienestar.htm (accessed on 12 August 2020).

75. Secretaría de Salud. Impacto Económico del Sobrepeso y la Obesidad en Mexico 1999-2023. Available online: http:/ / oment. salud.gob.mx/wp-content/uploads/2016/09/impacto_financiero_OyS_060815_oment.pdf (accessed on 11 August 2020).

76. Velázquez, V. Territorios Encarnados. Extractivismo, Comunalismo y Género en la Meseta Purépecha, 1st ed.; Universidad de GuadalajaraCIESAS-Jorge Alonso: Ciudad de México, Mexico, 2019.

77. Kay, C. Estudios rurales en América Latina en el periodo de globalización neoliberal: ¿una nueva ruralidad? Rev. Mex. Sociol. 2009, 71, 607-645.

78. Herrero, Y. Economía Feminista y Economía Ecológica. Rev. Econ. Crítica 2016, 22, 144-161.

79. Alvater, E. ¿Existe un marxismo ecológico? In Book La Teoría Marxista hoy: Problemas y Perspectivas; Boron, A., Amadeo, J., Eds.; Clacso Libros: Buenos Aires, Argentina, 2006; pp. 341-363.

80. Rosset, P.; Martínez, M. Agroecología, territorio, recampesinización y movimientos sociales. Estud. Sociales Rev. Investig. Científica 2015, 25, 275-299.

81. Cámara de Diputados. Constitución Política de los Estados Unidos Mexicanos. Available online: http:/ / www.diputados.gob $\mathrm{mx} /$ LeyesBiblio/pdf_mov/Constitucion_Politica.pdf (accessed on 11 August 2020).

82. Jusidman-Rapoport, C. El derecho a la alimentación como derecho humano. Rev. Salud Pub. Mex. 2014, 56, s86-s91. [CrossRef]

83. FAO; FIDA; UNICEF; PMA; OMS. El Estado de la Seguridad Alimentaria y la Nutrición en el Mundo. Fomentando la Resiliencia Climática en Aras de la Seguridad Alimentaria y la Nutrición. 2018. Available online: https://www.who.int/nutrition/publications/ foodsecurity / state-food-security-nutrition-2018-es.pdf (accessed on 11 June 2020).

84. Wolfson, J.A.; Leung, C.W. Food Insecurity and COVID-19: Disparities in Early Effects for US Adults. Nutrients 2020, $12,1648$. [CrossRef]

85. Figueroa-Pedraza, D. Vulnerable groups and their characterization like a discrimination criterion of food and nutritional security in Brazil. Rev. Bras. Saude Mater. Infant. 2005, 5, 367-375.

86. INFOSEN. Iniciativa con Proyecto de Decreto por el que se Adiciona un Artículo115 bis a la ley General de Salud y se Adiciona un Párrafo Tercero al Artículo 50 de la ley General de los Derechos de Niñas, Niños y Adolescentes, en Materia de Alimentos y Bebidas de alto Contenido Calórico. Available online: https://infosen.senado.gob.mx/sgsp/gaceta/64/2/2020-08-1 2-1/assets /documentos/Inic_Morena_Dip_Roberto_Hdz_art_115bis_50_ley_gral_ninas_ninos_adolescentes.pdf (accessed on 11 August 2020). 